\title{
Socialization of Homeless Children in the Society: the Problem of School Adaptation
}

\author{
Elena Kocai
}

Lithuanian University of Educational Sciences, Faculty of Social Education, Department of Social Work and Sociology, Studentų St. 39, LT-08106 Vilnius, Lithuania, elena.kocai@leu.lt

Annotation. Upon starting to attend school, a homeless child frequently faces the problem of stigmatization, lacks a wish for learning, as well as fails to learn and establish relationships with school community. Therefore, a child feels the situation of homelessness even more acutely. Homeless children that have difficulties in adapting at school, acquire no knowledge and skills, which would help them to overcome poverty and homelessness.

Keywords: a homeless child, care home, school.

\section{Introduction}

Topicality, problem and novelty of the research. Homelessness is one of the most urgent problems of social exclusion. The homeless can apply not to "façade spaces" but rather to "marginal areas" or "entrance through the inner yard", which is most frequently deserted and dull (according to the theory of dramaturgy by E. Goffman (2000)). Their private lives are both clear, simplistic and secret (they live in cellars and forlorn places). The homeless are characterized by poor economic, social, cultural and symbolic capital (the concepts of P. Bourdieu). They are almost independent from different institutions: educational, financial, labour, cultural and health protection. They do not have access to the media and information sources. They do not affect public life and even their own environment. They are losers, who have poor and undeveloped abilities, who do not create any material goods, do not have any power, privileges or status, as well as find it difficult to maintain personal dignity. Their emotions are preoccupied with the sense of loneliness and needlessness. 
The phenomenon of homelessness accompanies the humanity from the oldest historical times; however, homelessness has become extremely acute in modern societies. According to FEANTSA data, a large part of the European Union males, females and children are homeless (FEANTSA, 2010). Due to the long-lasting living on the street, care homes and other places, their fundamental human rights are violated. Homelessness is caused by different factors. They are not restricted merely to individual experiences or the ones based on social relationships, such as divorce, addiction, mental disability and violence. Structural factors, such as unemployment, poverty, limited possibilities to buy a living pace, discrimination and others, also play an important role in the process of homelessness. Institutional factors add up to the causes of homelessness: poor coordination of services, inadequate structuring of allowances and benefits. Unless policy makers take care of the problems, a lot of people will occur on the street and reside in temporary shelters for months or years.

The issue of homelessness is especially painful when speaking about children's homelessness. There are different categories of homeless children in different societies. The current article focuses on one of the categories, namely homeless children who have parents / care givers and live in temporary shelters (care homes). Such a choice is determined by the fact that residents and employees of care homes are more accessible to researchers rather than the street homeless (though they are more visible in public spaces and experience the most acute social exclusion).

Adaptation of homeless children at school is one of the primary steps of socialization in the society, which determines their further relationships with the social environment. It is obvious that the school cannot reduce the damage experienced by a child due to poverty and homelessness; yet it may become a fortress of stability at least in one sphere of life. According to the Convention of the Rights of the Child, the state should provide all the conditions for a child to lead a healthy life and development, protect him / her from violence and abuse, provide such protection and care which is necessary for his / her wellbeing. "There is no threat more severe than vagrant and uneducated children. They will show themselves in 10-15 when they grow up." (Kvieskiene, Merfeldaite, 2001).

Most children that grow in homeless families experience early social exclusion and insufficient care. These children are characterized by the lack of knowledge about the environment, poor social awareness, poor image, lack of general and abstract concepts, as well as disorders of language development. Having no safe environment and possibilities to satisfy their main needs, homeless children face the problem of exclusion not only in the society but also in the nearest environment, i.e. the school. Such children have to overcome a long and difficult process of school adaptation; they are characterized by slow social maturation of their personality. They are unable to adequately communicate with peers. Failure to learn and contempt by teachers, parents and classmates form a child's emotional and behaviour deviances and striving for revenge, which are often accompanied by depression, despair and apathy. 
School adaptation of homeless children (as well as the problem of homeless children itself) hardly receives any attention of Lithuanian researchers. Sociologists and representatives of social policy mostly focus on the lifestyle and social exclusion of adult homeless people. The homeless were investigated by V. Kanopienė (2004), J. Sadauskas (2008), and E. Kocai (2006-2014). There are a few works on the problems of "street children" by J. Kvedaravičiūtè (2007), I. Bulotaitè (2000), G. Kvieskiené, and O. Merfeldaitė (2001). School adaptation of homeless children was addressed by L. Norkūnaitè (2012), a Master degree student of Lithuanian University of Educational Sciences (scientific supervisor E. Kocai). The problems of the stigmatization of these children at school were explored by E. Kocai and V. Ratkevičienè (2012).

The task of sociologists is to collect as much information about life problems of homeless children, i.e. living conditions of their families, adaptation in the living place, school, etc, which can prevent their spread. The goal of this article is to explore the peculiarities of the adaptation of homeless children at school. Attempts to approach socially excluded groups by investigation allow reducing social distance in the society. This enables to overcome stigmatic stereotypes and disclose unpleasant but highly important topics.

Research methodology. The current article analyzes school adaptation of homeless children following the theory on the models of a person's social adaptation in the society, developed by American sociologist R. Merton. He defined five types of personal adaptation: conformity, innovation, ritualism, retreatism and rebellion. It must be pointed out that this classification is applicable to people, who belong to the lowest layers of the society (the layer of the homeless, in our case).

Description of the research. The research was conducted in Vilnius city in 2012 by E. Kocai and L. Norkūnaite. The research involved homeless children, who resided in care homes in Vilnius city. The sample involved 8 juvenile children aged 6 to 15 , who attended school. The researchers obtained written permissions from their parents to carry out a survey. The method of the research was an interview.

The types of homeless children's school adaptation are explored using open-ended questions about their being at school, relationships with peers and teachers, as well as success and failure in learning. Research data were analyzed using the method of qualitative content analysis. The empirical part included a descriptive method, which is applicable to unexplored or fairly explored fields.

The research does not claim for representation; yet it reveals some problematic aspects in the context of the problem under analysis.

\section{Social exclusion and homelessness in the world}

Historians, sociologists, anthropologists and politicians agree that social exclusion is a feature of every society. Throughout the whole history and in the whole world there 
has been no culture, which would not display stigmatization, separation and exclusion of social groups in one form or another. Social exclusion has always existed with the differences in the nature, scope and outcomes of its manifestation. International experience demonstrates that social exclusion becomes a state problem not only in the developing countries but also in the societies that have deep democratic traditions.

The latest statistics show that more than 100 million of EU population live in poverty and suffer from social exclusion. Despite that EU leaders promise that the problem will be reduced by 2020 and that at least 20 million of residents will overcome poverty, experts believe that poverty and exclusion have recently been accelerating in the EU. Millions of European residents are on the edge of social bottom, which is manifested by 2011 statistics:

- $24 \%$ of all EU residents (120 million people) are in danger of poverty or social exclusion, which makes $27 \%$ of all European children;

- almost $9 \%$ of all Europeans live in great financial deprivation;

- $10 \%$ of Europeans live in households and are unemployed;

- The number of females living in poverty exceeds the number of males by 12 million (European Commission).

The research demonstrates that persons with poor physical and mental health, who are in poverty or whose environment is unsafe, tend to be socially excluded (Mikulioniene, $2005,28)$. The following groups are at the greatest risk of social exclusion:

- Children and teenagers that do not attend school;

- uncared children;

- People living on the street, in care homes and hostels;

- Former prisoners and members of their families;

- Refugees looking for shelter;

- Drug addicts;

- Roms (Breaking the Cycle: a Report by Social Exclusion Group, 2004, 25).

On the one hand, social exclusion always reflects certain marginal processes in a socium, which lead the most vulnerable members of the society to poverty, despair and passivity; on the other hand, it destroys the fundamentals of a democratic society, promotes nihilism and social hostility.

Homelessness is a marginal form of poverty and social exclusion. Statistical data demonstrate that there are about 700 million homeless people in the world. This number involves both real and potential homeless people: 100 million people do not have any shelter; 600 million live in care homes and unsafe places (Encyklopedia socjologii, 2002, 61).

In the process of becoming homeless, a person experiences the processes of both exclusion and integration. Firstly, the process of social exclusion takes place. Leaving the normal society, a homeless person integrates into the homeless community and finds him / herself in a marginal culture, where s / he becomes normal (Sadauskas, 2010, 448). Being excluded from the society, a person loses former social ties, his / her needs and lifestyle undergo certain changes. A homeless person experiences exclusion in all aspects: 
social, economic, cultural, institutional, political, geographical and others. A homeless person excluded from the participation in social life, is "lost" for the society from the point of view of human resources.

\section{The phenomenon of child homelessness}

The conception, scope and causes of child homelessness. Who is a homeless child? It is difficult to answer this question as the official definitions of homelessness differ greatly in different countries. For example, homelessness if often perceived as merely having no home: the homeless are the ones who have no permanent living place. This is a very narrow conception of homelessness. Some scientists maintain that homelessness covers more than merely having no home. According to them, it includes lack of safe, cozy and comfortable home. Consequently, the homeless are also the ones, who do not possess own home and live temporarily in different establishments (care homes, penitentiary institutions, etc).

Homeless children are children up to 18 years of age, who do not have a permanent living place or cannot use it temporarily, who live in accidental places, temporary shelters, and whose parents (if they are) cannot afford buying or renting a living place. When a child or an adolescent finds him / herself outside the former social group and does not have a permanent living place, $s$ / he tends to acquire specific features characteristic of the homeless, and takes over the norms and values of this category of people.

In most countries the statistical data on the homeless are not accurate. Hence, the inaccurate number of the homeless is a common problem, which is emphasized by a great number of researchers. The scope of homelessness in one country or another is difficult to determine as most homeless people do not have personal documents and do not turn to social institutions. It is equally difficult to compare the spread of homelessness in different countries. Firstly, no country possessed exact data on this layer of the society. Secondly, the periods of collecting statistical data and criteria of attributing a person as homeless differ. Besides, academic communities of different countries do not have a uniform conception of the phenomenon of homelessness and definition of the homeless. The same situation is observed with the identification of the number of homeless children.

There are no exact data on child homelessness in Lithuania and the world. There exist only episodic and loose data on homeless children in some states. For instance:

- statistical data of the USA shows that 45 children become homeless every year; there are 1.6 million homeless children in total (The National Center on Family Homelessness, 2013);

- in Poland the number of homeless children ranges up to 100 thousand (Niechciane. Już 100 tys. bezdomnych dzieci w Polsce, 2013); and there are some data, which show that there are as far as 19 thousand; 
- according to unofficial data, there are 150-160 thousand of homeless children in the Ukraine, whereas the official data claim 12 thousand of homeless 10-19 year olds (В Украине официально 30 тысяч бездомных, а неофициально - 130 тысяч, 2012);

- in Russia, out of 40 million children (up to 18 years old), homeless children constitute $1 \%$; however, this number is growing.

As it is seen from Table 1, homeless children in Lithuania constituted 5\% of the total number of homeless people in 2001. It is assumed that currently this number is bigger as the rate of homelessness is constantly growing throughout the world.

Table 1. Distribution of Lithuanian homeless people according to age groups

\begin{tabular}{|c|c|c|}
\hline Age & Number & Percentage \\
\hline $0-20$ & 67 & 5 \\
\hline $21-30$ & 91 & 7 \\
\hline $31-40$ & 259 & 21 \\
\hline $41-50$ & 388 & 31 \\
\hline $51-60$ & 295 & 24 \\
\hline 61 and older & 143 & 11 \\
\hline Unspecified & 7 & $\sim 1$ \\
\hline
\end{tabular}

${ }^{\star} 2001$ population census, www.stat.gov.lt

Homeless children living in care homes. Three types of homeless children are constructed in a social space in accordance with the living place: children living in a temporary shelter (care home), dumping grounds and the street. Distribution of the homeless according to living place is a category that is most obvious and easily measured. Living place is a constituent part of the social structure, which determines the lifestyle of a person (group). It largely affects a person's daily routine, nutrition, health and consumption. The environment and lifestyle of each group of homeless people is distinct and possesses particular features.

As it was mentioned before, the current article focuses on one of the groups of homeless children, namely children living in care homes.

Care homes (temporary living places) are institutions of social care that provide temporary social care for the homeless or the ones who have temporary restriction to own living place (LR Socialinès apsaugos ir darbo ministerijos įsakymas „Dèl socialinių paslaugų katalogo patvirtinimo", 2006). They also provide diverse social assistance and help to solve the incurred problems. Currently there are 22 care homes in Lithuania, which are maintained from municipal funds and provide 1138 places of temporary lodging and 238 places for a night's stay. According to the data of the Statistics Department, a special social service of temporary lodging was provided to 1980 people in 2008: out 
of them 421 females and 1469 males (The Statistics Department by the Government of the Republic of Lithuania, 2010). Care homes serve as mediators for a person seeking for permanent lodging; yet these services are provided only temporarily. Unfortunately, the aforesaid form of lodging frequently becomes more permanent than it is expected. Therefore, people often live in an inappropriate situation for a long time.

Homeless children living in care homes (up to 18 years of age) usually live with their parents. Hence, attention is focused on homeless families having children. Usually these are single mothers having one or more children.

There are different factors that determine children's homelessness: socio-psychological, socio-economic, natural and others. It is obvious that the causes of their homeliness lie primarily in the family of parents / care givers: there may be financial or accommodation problems, parents' alcoholism, violence and the like. Children become homeless for various reasons; however, the primary reasons are related to parents' homelessness, caused by their alcoholism, unemployment, divorce, poverty, etc.

Homelessness affects all family members, especially physical and mental health of children. It is especially harmful in the first years of childhood; though it also causes great problems later while attending the school, etc.

\section{The school as a factor of socialization of homeless children: challenges and opportunities of adaptation}

Socialization and the formation of personality. Socialization is a way of acquiring behaviour norms, thinking styles, feelings, knowledge, motivation and value-based orientations through social environment. This process is implemented through observation, imitation, comparison, avoidance, experimenting and awareness. It may be intensive or slow. Homan socialization begins with the birth and continues throughout the whole life. A young person acquires social experience in different spheres of life, which permit to perform different social roles. Hence, socialization is perceived as a process, condition and final result of the social formation of a personality.

The process of socialization is implemented in accordance with the system of different social institutes. It is not confined to the family, but it occurs in other large and small groups. The school is one of the primary models of a child's social world. In its broadest sense, the school provides not only formal and systematic education, but also introduces with the non-formal and unwritten rules and provisions.

Social adaptation. Socialization is an essential condition of adaptation, i.e. adaptation is the first step of socialization. An unsocialized person is unable to adapt in the society. Adaptation can be analyzed not only as the adaptation of an organism to the environment, but also from the social point of view, i.e. as a process of a person's active sharing of human experience and adaptation to the changing environment. 
American sociologist R. Merton developed as scheme of the types of personal adaptation related to the social roles of an individual. Table 2 demonstrates that an individual's wish to attain the goal in a complex hierarchy of social norms, values and institutions using available means forces him / her to adapt to the society. Differentiation criteria depend on how the goals and means chosen by the individual are valued by the society.

Table 2. Typology of individual adaptation types

\begin{tabular}{|ll|c|c|}
\hline & Type of adaptation & Goals & Institutionalized means \\
\hline I. & Conformity & + & + \\
\hline II. & Innovation & + & - \\
\hline III. & Ritualism & - & + \\
\hline IV. & Retreatism & - & - \\
\hline V. & Rebellion & $+(-)$ & $+(-)$ \\
\hline
\end{tabular}

$(+)$ - acceptance; $(-)$ - rejection; $(+,-)$ - rejection of current values and their substitution by new values.

R. Merton maintains that due to the antithesis of social and value-based structures an anomy occurs between the socially legitimate goals and available means to achieve these goals. Pursuing to overcome this antithesis, different ways of action are chosen (Merton, 1997, 71):

Conformity occurs when individuals accept the culturally defined goals and the socially legitimate means of achieving them. Ritualism occurs when a person conforms to the socially accepted behaviour standards despite that they lose their real value. Retreatism presupposes rejection of cultural / social goals and legitimate means; a typical example is retreat to social margins - abuse of alcohol and drugs, vagrancy or belonging to a sect. Innovation means that cultural / social goals are accepted but they are attained by illegitimate means. The result is delinquent behaviour. Rebellion is such a way of adaptation when general values and means of their attainment are completely rejected; however, new values and revolutionary means to achieve them are introduced in the social system.

These types of adaptation are a certain safety mechanism, which helps an individual to overcome psychological discomfort. Such a model can also be applied to analyze the adaptation of homeless children at school.

Children's adaptation at school is an important element of school socialization. According to S. Burvyte, "adaptation is a process when a learner actively participates and behaves in creating social outcomes. School adaptation is most often perceived as an appropriate interaction of a learner with the environment. Its opposition is a deficiency of this interaction, which inhibits a child's development and satisfaction of his / her needs" (Burvytè, 2004, 83-88). 


\section{School adaptation of homeless children: analysis of research data}

How does adaptation occur at school, what problems do learners face at school? Firstly, let us analyze who the children of care homes are.

The contours of the social portrait of homeless children. All the children, who participated in the research, live in care homes with their mothers or other relatives - fathers, brothers or sisters. Two of the children live with both parents and two / three siblings. The others live with single mothers and one / two / three siblings. Such families can be called homeless, and the children can be referred to as homeless children. All the families live in poverty, usually on state allowances. The parents set inappropriate examples for their children, the living conditions are unsafe and usually dependent on others' mercy. The numbers of such families are not fixed as some families move in and some of them move out. Therefore, it is difficult to determine the exact number of children living in such institutions (e.g. there lived 7 children, 150 females and 133 males in care home in April 2014). The age of children differs from new born to teenagers. All children of school age attend school but face certain problems: they frequently change school because they are unable to adapt in them. These children are characterized by problematic behaviour (they use swear-words, fight, show disobedience and demand everything by shouting), hyperactivity, inability to communicate, lack of amiability, and inability to tell about their feelings. It is understandable that homeless life has affected the fate of these children.

School difficulties. Unfavourable position of homeless children leads to the development of school difficulties. This is an important factor, as children do not feel safe at school: they have to reconcile themselves to abuse arising from the fact that they do not have the same living conditions as others. Unsuccessful school adaptation determines the factor of negative labeling. Children are perceived as "lacking kindness", "devoid of parents' support' and "looking for close people". Informant NN6 maintains that "teachers and classmates do not care about me; they have a negative opinion of me and speak only bad things about me that I am a derelict and so on and so forth". Therefore, homeless children communicate only with children of a similar social status both in the living place and at school. Informant NN1 states that "my teacher does not like me, and some classmates are so stupid and always talk bad things about me and my family".

A very important factor that influences learners' failed adaptation is the difficulties of communicating with peers and teachers. According to M. Barkauskaitè and K. Mišeikytè, a child's wellbeing at school depends on teaching materials and curriculum as well as the very organization of teaching process, teacher-learner interaction and school climate (Barkauskaitè, Mišeikytè, 2006, 127-134). Learning difficulties occur due to negative emotions, feelings and experiences, which embarrass the learner. The learning results become worse; the child demonstrates passive or active protest, negative behaviour and refuses to accomplish different tasks. The learner feels incompetent and cannot apply his/ 
her abilities. S/he frequently misunderstands the study subjects and skips classes, which is turn leads to a greater gap in knowledge. NN5 reports that "I like going to school, but most often I dislike it as different imbeciles make me nervous. And I don't understand all the subjects".

The process of failed adaptation of homeless children at school develops in accordance with the principle of "a defective closed circle". Unwillingness to attend school occurs due to the misunderstandings with classmates and teachers and learning failures. However, this controversy occurs because o negative labeling and attempts to fight for one's place in the world. Luckily, the results of the interview show that homeless children strive for feeling full-fledged members of school community, as well as develop constructive relationships with classmates and teachers.

According to S. Burvyte, "failed school adaptation in its broadest sense or adaptation difficulties are perceived as the totality of factors related to the unconformity of socio-psychological and psycho-physical status of a child and requirements for the teaching situation". The aggregate of these causes make a person's life complicated and at some cases impossible (Burvytè, 2004, 88).

Types of homeless children's adaptation at school. Children from care homes solve school problems by adjusting to the circumstances: they either retreat or, on the contrary, become aggressive towards others. Homeless children are mostly attributed to the social adaptation types of rebellion or retreatism.

\section{Table 3. Types of school adaptation of homeless children}

\begin{tabular}{|c|l|l|}
\hline \multicolumn{1}{|c|}{ Category } & \multicolumn{1}{|c|}{ Subcategory } & \multicolumn{1}{c|}{ Statement } \\
\hline \multirow{2}{*}{$\begin{array}{l}\text { Types of school } \\
\text { adaptation }\end{array}$} & $\begin{array}{l}\text { NN7 "I am a grown up and can tell that I don't like going } \\
\text { to school. I hate the discipline during lessons, and some } \\
\text { classmates I disagree with. There were some cases when I } \\
\text { had to fight with some girls." }\end{array}$ \\
\cline { 2 - 3 } & Retreatism & $\begin{array}{l}\text { NN8 "I do not communicate with children at school. I } \\
\text { only communicate with peers from the care home. They } \\
\text { understand me, and I understand them. Other people } \\
\text { consider me as a different one, the one who has no home. } \\
\text { So I spend most of my time here, in my environment." }\end{array}$ \\
\hline
\end{tabular}

The child that belongs to the type of rebellion has a difficult character, is inclined to solve problems by fueling them, is often hostile to others and creates new rules of intolerable behaviour. The aggressive behaviour of these children becomes a means of consolidation. These children know that they are strongest among others; therefore, striving for strength and power is among the top values.

The child that belongs to the type of retreatism behaves in an opposite way: $/$ / he tries to avoid conflict situations, does not show own emotions and is rather introvert. Home- 
less children are not inclined to communication with classmates at school, try avoiding them and choose friends from own environment, i.e. other families living in care homes.

\section{Conclusions}

1. Children of care homes fall into two types of social adaptation: rebellion and retreatism. On the one hand, the selected roles limit their social interaction; on the other hand, they help surviving in the current situation.

2. Factors inhibiting successful school adaptation of homeless children are stigmatization and specific lifestyle. A negative portrait of a child is drawn in accordance with the public contempt for a homeless family. Another factor is the expression of homeless lifestyle in the behaviour of homeless children.

3. In conclusion, it is possible to claim that children from care homes face a number of problems at school: learning failures, miscommunication, etc. Both children and their parent demand substantial support as they have appeared in a closed-ended circle and have difficulties of adapting in the society. This directly affects their children and their vision of current and future life.

\section{References}

Barkauskaitė, M., Mišeikytė, K. (2006). Mokinių adaptacijos ypatumai krizinių ugdymo(si) etapų metu. Pedagogika, 84.

Burvyte, S. (2004). Adaptacija ir jos raiška pradinejje mokykloje. Pedagogika, 73.

Breaking the Cycle: a Report by Social Exclusion Group. (2004). London.

Encyklopedia socjologii. (2002). Warszawa: Oficyna naukowa.

European Commission. Employment, Social Affairs \& Inclusion. Poverty and social exclusion. Prieiga per internetą: http://ec.europa.eu/social/main.jsp?catId=751\&langId=en.

FEANTSA biuro informacija. Panaikinti benamyste yra i̇manoma. (2010). Prieiga per internetą: http://www.feantsa.org.

Goffman, E. (2000). Savęs pateikimas kasdieniame gyvenime. Vilnius: Vaga.

Kocai, E. (2007). Socialine benamiu atskirtis ir jos formavimosi veiksniai. Daktaro disertacija. Vilnius: STI, VU.

Kvieskienè, G., Merfeldaite, O. (2001). Gatvès vaiko atskirties ir reintegracijos problemos. Prieiga per internetą: http://etalpykla.lituanistikadb.lt/fedora/objects/LT-LDB0001:J.04 2001 1367181488512/datastreams/DS.002.0.01.ARTIC/content.

LR socialines apsaugos ir darbo ministerijos isakymas „Dèl socialiniu paslaugu katalogo patvirtinimo“. (2006). Prieiga per internetą http://www3.lrs.lt/pls/inter2/dokpaieska. showdoc_l?p_id=274453\&p_query=\&p_tr2=. 
Lietuvos statistikos departamentas prie LR Vyriausybès. Prieiga per internetą: http://www.stat.gov.lt. Merton, R. (1997). Socialinè struktūra ir anomija. Sociologija. Mintis ir veiksmas, 1.

Mikulionienè, S. (2005). Socialinè atskirtis: sąvokos samprata ir vartosena Lietuvoje. Socialinis darbas, 4 (2).

Niechciane. Już 100 tys. bezdomnych dzieci w Polsce [žiūrèta 2013 m. vasario 20 d.]. (Polityka, Onet/JM; Pog). Prieiga per internetą: http://wiadomosci.onet.pl/kraj/niechciane-juz-100-tysbezdomnych-dzieci-w-polsce/cx6rm.

Norkūnaitè, L. (2012). Nakvynès namuose gyvenančių vaikų adaptacijos ypatumai Vilniaus miesto mokyklose. Magistro darbas. Vilnius: LEU.

Sadauskas, J. (2010). Socialinis darbas su benamiais. In Socialinis darbas. Profesiné veikla, metodai ir klientai. Vilnius: MRU.

The National Center on Family Homelessness. Children. (2013). Prieiga per internetą: http://www. familyhomelessness.org/children.php? $\mathrm{p}=\mathrm{ts}$.

В Украине официально 30 тысяч бездомных, а неофициально - 130 тысяч [žiūrèta 2012 m. birželio 7 d.]. Prieiga per internetą: http://vvc.kiev.ua/news/1040.

Европа задыхается от обилия бездомных и нищих. 14 октября 2013, 14:24 (мск) | Политика | Радио «Голос России». Prieiga per internetą: http://news.mail.ru/politics/15185023/.

\section{Benamių vaikų socializacija visuomenëje: adaptacijos problema mokykloje}

\section{Elena Kocai}

Lietuvos edukologijos universitetas, Socialinės edukacijos fakultetas, Socialinio darbo ir sociologijos katedra, Studentuc g. 39, 08106 Vilnius, elena.kocai@leu.lt

\section{Santrauka}

Benamių vaikų adaptacija mokykloje yra vienas iš pirminių ir svarbiausių socializacijos visuomenejje žingsnių, nuo kurio gali priklausyti, kaip toliau klostysis jų santykiai su socialine aplinka. Sèkmingas ar nesèkmingas adaptavimasis mokykloje gali lemti vaiko ugdymo ir mokymo(si) rezultatus, tai, koki gyvenimo būdą (vertybes, nuostatas, elgesi) pasirinks ateityje.

Mūsų tyrimas atskleidè, kad nepalanki vaiko padètis benamëje šeimoje, gyvenančioje nakvynès namuose, sudaro sąlygas mokykliniams sunkumams atsirasti, ir šis faktorius labai reikšmingas. Mokykloje benamiai vaikai jaučiasi nesaugiai, iš kitų vaikų patiria patyčių ir smurto dèl to, kad gyvena kitaip nei dauguma mokyklos vaikų. Nesėkmingą 
vaikų adaptaciją mokykloje lemia neigiamų „etikečių klijavimo“veiksnys. Vaikai ịsivaizduojami kaip „stokojantys šilumos“, „netekę tèvų paramos“, ,ieškantys artimų žmonių“. Vaikai iš nakvynès namų mokykloje kylančias problemas sprendžia prisitaikydami prie aplinkybių - arba pasitraukia, arba, atvirkščiai - pasidaro agresyvesni aplinkiniams. Benamiai vaikai mokykloje linkę i maištininko ir atsiskyrèlio socialinio adaptavimosi tipus. Kita vertus, džiugu tai, kad iš apklausos pastebimas benamių vaikų noras mokykloje jaustis visaverčiais bendruomenès nariais, turèti konstruktyvius santykius su klasès draugais ir mokytojais.

Esminiai žodžiai: benamis vaikas, nakvynès namai, mokykla.

Iteikta / Received 2014-09-05

Priimta / Accepted 2014-10-12 